consistent with previous British reports ${ }^{2}$ and reflects the prevalence of antibody to the virus found in the same age group in the West Indies. ${ }^{3}$ No cases of infection were identified among the 214 black women who had been born in the United Kingdom, but the fairly small sample allows us to state only that the prevalence in this group was unlikely to be more than $1 \cdot 7 \%$. These women were young (mean age 19.5 years), and as there is evidence that infection can be acquired throughout adult life $^{3}$ a sample more representative in age might have shown a higher prevalence of infection.

Though the risk of maternal transmission of the virus to infants born in Japan is high, ${ }^{+}$the risk in the United Kingdom is unknown. There is also little prospective information on the importance of carriage of the virus, which makes it difficult to counsel carriers.

Our data suggest that a reservoir of undiagnosed female carriers of human $\mathrm{T}$ cell leukaemia/lymphoma virus type I exists in the United Kingdom, but before widespread screening for antibody to the virus is considered more data are needed on the prevalence of infection in other regions of the United Kingdom, the risk of transmission from mother to child, and the long term consequences of infection with the virus.

We are grateful to J E Richmond for help with handling the data.

1 Catovsky D, Rose M, Goolden AWG, et al. Adult T-cell lymphoma/leukaemi in blacks from the West Indies. Lancet 1982;i:639-43.

2 Mowbray J, Mawson S, Chawira A, et al. Epidemiology of human T-cell leukemia/lymphoma virus type I (HTLV-I) infections in a subpopulation of Afro-Carino

3 Clark J, Saxing C, Gibbs WN, et al Seroepidemich cell leukemialymphom cell leukeniahy pathway for peculiar endemia. Asian Medical fournal 1989;32:239-45.

(Accepted 3 April 1990)

\section{Hypothyroidism in polymyalgia rheumatica and giant cell arteritis: lack of any association}

\section{B Dasgupta, E Grundy, E Stainer}

\section{Departments of}

Rheumatology, Clinical

Chemistry, and

Immunology, Royal Sussex

County Hospital, Brighton,

Sussex

B Dasgupta, MRCP, senior

registrar

E Grundy, DPHIL, principal

biochemist

E Stainer, senior medical

laboratory scientific officer

Correspondence to: $\mathrm{Dr}$ B Dasgupta, Rheumatology

Unit, Guy's Hospital,

London SE1 9RT.

BrMed f 1990;301:96-7 et al.

\section{Patients, methods, and results} giant cell arteritis (based at Guy's Hospital, London).
Wiseman et al have described a study showing an association between hypothyroidism and polymyalgia rheumatica and giant cell arteritis. ${ }^{1}$ This prompted us to perform thyroid function tests and tests for thyroid antibodies on stored serum samples from patients with polymyalgia rheumatica and giant cell arteritis. Our results and conclusions differ from those of Wiseman

Serum samples obtained during two prospective studies were stored at $-20^{\circ} \mathrm{C}$. The first was a multicentre study in the South East Thames region to determine the numbers of CD8 + cells in peripheral blood in patients with polymyalgia rheumatica and The second was a study of the treatment of polymyalgia rheumatica with intramuscular methylprednisolone (based at Royal Sussex County Hospital, Brighton). Polymyalgia rheumatica and giant cell arteritis had been diagnosed from clinical features, the erythrocyte sedimentation rate, $\mathrm{C}$ reactive protein concentration, and a good response to corticosteroids. None of the patients had a history of thyroid disease or were taking thyroxine. Prior exclusion of hypothyroidism was not a criterion for entry of patients into either study.

Serum samples from 77 patients ( 69 with polymyalgia rheumatica and eight with giant cell arteritis) were studied. The mean ages of patients in the two studies were $72 \cdot 4$ and $70 \cdot 3$ years respectively. Free thyroxine and free triiodothyronine concentrations were measured indirectly by measuring total thyroxine and total triiodothyronine by a standard radioimmunoassay; measuring thyroxine binding globulin with a tracer binding assay; and then calculating the concentrations of free hormones. ${ }^{2}$ Thyroid stimulating hormone was measured by MA1A clone assay (Sero Diagnostics, Woking, Surrey). Thyroid antibodies were measured by rapid particle agglutination tests with the commercial test kits Thymune $\mathrm{T}$ and Thymune $\mathrm{M}$ (Fujirubio).

None of the 77 patients showed biochemical evidence of hypothyroidism; one was borderline for hypothyroidism and one clearly had hyperthyroidism.
Three patients had low concentrations of antibodies to thyroglobulin and microsomal antigen, and five had antibodies to microsomal antigen only.

Clinical features of hypothyroidism were not recorded in any of the 62 patients from the first study. A retrospective examination for clinical hypothyroidism, such as delayed relaxation of ankle jerks, did not show any abnormalities among the 15 patients from the second study.

\section{Comment}

Our study failed to find any association between biochemical hypothyroidism and polymyalgia rheumatica or giant cell arteritis. The study by Wiseman et al was a retrospective study of the patients' notes, and it is always difficult to ensure that all patients with a particular condition are truly included in such studies.

In their report Wiseman et al did not describe how the patients' thyroid state had been ascertained - that is, there was no indication of which thyroid function tests had been carried out. This is especially relevant because the mean age of patients in their study was high $(80.5$ years). In such patients sickness in general may be associated with a "sick euthyroid" state in which serum triiodothyronine and occasionally thyroxine concentrations are low but do not connote hypothyroidism. It would have been useful to know whether they also measured serum thyroid stimulating hormone concentrations.

Another possible explanation might be that hypothyroidism in itself may present with quite severe myalgia, muscle stiffness, and a raised creatine kinase concentration and thus mimic polymyalgia rheumatica or myositis. We wonder whether this factor might have accounted for the high incidence of hypothyroidism (nine out of 15) seen by Wiseman et al in their patients with polymyalgia rheumatica.

Because polymyalgia rheumatica, giant cell arteritis, and hypothyroidism are fairly common conditions in the elderly, the coincidental development of two separate diseases in the same patient might explain why there are reports of these conditions coexisting. In our study the thyroid antibody concentrations in the serum samples were all low and were no higher than those in the general population. ${ }^{3}$ The only autoantibodies that occur in higher concentrations in polymyalgia rheumatica and giant cell arteritis are antibodies to intermediate filaments.

We think that hypothyroidism is an important differential diagnosis in the clinical presentation of polymyalgia rheumatica but that any true association 
between idiopathic polymyalgia rheumatica and hypothyroidism is unlikely.

I Wiseman P, Stewart K, Rai GS. Hypothyroidism in polymyalgia rheumatica and giant cell arteritis. Br Med f 1989;298:647-9.

2 Grundy EN. Assessment of thyroid function. Brighton: University of Sussex, 1979:260-75. (PhD Thesis.)
3 Burgi $\mathrm{H}$. The thyroid gland. In: Labhart A, ed. Clinical endocrinology, theory and practice. 2nd ed. Berlin, Heidelberg: Springer Verlag, 1986:181-348.

4 Dasgupta B, Duke O, Kyle V, Macfarlane DG, Hazleman BL, Panayi GS. Antibodies to intermediate filaments in polymyalgia rheumatica and giant cell arteritis: a sequential study. Ann Rheum Dis 1987;46:746-9.

(Accepted 28 February 1990)

\section{Reactivation of rheumatoid arthritis during continuous infusion of interleukin 2: evidence of lymphocytic control of rheumatoid disease}

\author{
M Lavelle-Jones, A Al-Hadrani, E M Spiers, \\ F C Campbell, A Cuschieri
}

Ninewells Hospital and Medical School, Dundee DD1 9SY

M Lavelle-Jones, FRCS, lecturer in surgery

A Al-Hadrani, FRCS, research fellow, department of surgery

E M Spiers, MRCP, registrar, department of pathology

F C Campbell, FRCS, senior lecturer in surgery

A Cuschieri, MD, professor of surgery

Correspondence to:

Professor Cuschieri.

Br.Med f 1990;301:97

Frequent toxic complications during bolus administration of interleukin 2 as immunotherapy for cancer led to the use of continuous infusion of the drug, which is better tolerated. We report on a patient with metastatic colorectal cancer whose rheumatoid arthritis recurred during continuous infusion of interleukin 2 .

\section{Case report}

A 57 year old woman with quiescent rheumatoid arthritis whose symptoms were controlled with paracetamol presented with weight loss and iron deficiency anaemia. Examination showed a large pelvic mass, and a poorly differentiated carcinoma of the sigmoid colon was confirmed by colonoscopy and biopsy. At laparotomy the disease was found to be extensive locally and to affect adjacent small bowel. There were multiple metastatic deposits in the right lobe of the liver. The sigmoid colon and the affected small bowel were resected, and gastrointestinal continuity was restored by two separate end to end anastomoses. Because of residual hepatic disease she was entered into a trial in which patients with advanced colorectal cancer were given a continuous infusion of recombinant interleukin $2\left(18 \times 10^{6} \mathrm{IU} / \mathrm{m}^{2} /\right.$ day for five days $)$ and sequential fluorouracil $\left(80 \mathrm{mg} / \mathrm{m}^{2}\right.$ weekly intravenous injection for three weeks) (Eurocetus EC-MP-004 trial). The first treatment cycle began four weeks after her operation.

Forty eight hours after the infusion of interleukin 2 was started the patient complained of a progressive, acute arthropathy affecting the knees, elbows, and neck; previously her wrists and metacarpophalangeal joints had been affected. Her serum concentration of rheumatoid factor had risen from 0 to $22 \times 10^{4} \mathrm{IU} / \mathrm{l}$ and the circulating concentration of $\mathrm{C}$ reactive protein from 31 to $120 \mathrm{mg} / \mathrm{l}$. The mean serum interleukin 2 concentration during the infusion was $24 \times 10^{3} \mathrm{IU} / 1$. Because of progressive pain, which did not resolve when the rate of the infusion was reduced or when naproxen $500 \mathrm{mg}$ twice daily was added, the infusion was stopped and her symptoms controlled with systemic steroids. Changes in circulating lymphocyte concentrations were consistent with those seen during treatment with interleukin 2 , the total lymphocyte count dropping from $2.4 \times 10^{9} / 1$ to a nadir of $0.6 \times 10^{9} / 1$ during infusion. When treatment was withdrawn a rebound lymphocytosis occurred $\left(4 \cdot 2 \times 10^{9} / 1\right)$ and the serum concentration of rheumatoid factor fell to $5 \times 10^{4}$ IU/l within 72 hours.

\section{Comment}

Clinical studies of bolus injections of interleukin 2 as immunotherapy have shown a multisystem toxicity related to the dose, the most serious effect being a microvascular capillary leak syndrome producing hypotension, oliguria, and pulmonary oedema. Constant infusions of interleukin 2 maintain the cytotoxic lymphoproliferative response and avoid these life threatening side effects. Because interleukin 2 acts by promoting an immune response to the tumour itself toxicities relating to disturbances in immune function are not unexpected. To our knowledge, this is the first report of an exacerbation of rheumatoid arthritis induced by interleukin 2. Current evidence supports the concept that the inflammatory response in rheumatoid arthritis is caused by a synovial infiltrate of activated inflammatory cells, including $\mathrm{T}$ lymphocytes, that secrete a variety of cytokines. ${ }^{1}$ Their importance in the pathogenesis of rheumatoid arthritis is supported by the clinical improvement seen in patients after drainage of the thoracic duct and lymphocytapheresis. ${ }^{2}$ Although controversy exists over the quantity of interleukin 2 in the rheumatoid joint, ${ }^{3}$ this cytokine may stimulate the functions of CD4 T cells, B cells, and macrophages locally with subsequent release of factors that mediate inflammation and rheumatoid factor. ${ }^{+}$This would explain the exacerbation of rheumatoid arthritis induced in our patient after infusion of a fairly large dose of interleukin 2 .

Our experience suggests that immunotherapy with interleukin 2 should be used with caution in patients with rheumatoid arthritis. These patients might derive benefit from an inhibitor of cyclo-oxygenase such as ibuprofen before and during treatment with interleukin 2 as ibuprofen has recently been shown to reduce the toxic effects associated with this treatment. ${ }^{5}$

1 Jira M, Malkovsky M, Denmen AM, et al. Lymphokine activated killer cell activity in rheumatoid arthritis. Clin Exp Immunol 1987;68:535-42.

2 Karsh J, Klippel JH, Plotz PH, et al. Lymphapheresis in rheumatoid arthritis. Arthritis Rheum 1981;24:867-73.

3 Buchan G, Barrett K, Fujita T, et al. Detection of activated T cell products in the rheumatic joint using cDNA probes to interleukin-2 (IL-2) receptor and IFN-gamma. Clin Exp Immunol 1988;71:295-301.

4 Weiss A. T lymphocytes. In: Kelly WN, Harris ED, Ruddy S, Sledge CB, eds. Textbook of rheumatology. Philadelphia: W B Saunders, 1989:148-61.

5 Eberlein TJ, Schoof DD, Michie HR, et al. Ibuprofen causes reduced toxic effects of interleukin 2 administration in patients with metastatic cancer. Arch Surg 1989;124:542-6

(Accepted 20 April 1990)

\section{Correction}

Somatostatin analogue treatment for malignant hypercalcaemia

An authors' error occurred in this short report by Dr $M$ Harrison and others (19 May, p 1313). The dosage of octreotide given was $50 \mu \mathrm{g}$ to $100 \mu \mathrm{g}$ twice a day and not $50 \mathrm{mg}$ to $100 \mathrm{mg}$ as published. 